\title{
Pod Borer of Peanut and Potential Entomopathogenic Fungi for its Control in West Sumatera
}

\author{
Reflinaldon, Trizelia, Hasmiandy and Jamilah Ganeshi \\ \# Department Plant Pests \& Diseases, Faculty of Agriculture, Andalas University, West Sumatera, Indonesia \\ E-mail: refli_naldon@yahoo.com
}

\begin{abstract}
Pod borer (Etiella zinckenella) is a serious pest on peanuts in West Sumatera since the last four years. The larvae lived and bored on pods under soil surfaces and it is often undetected. E. zinckenella is very limited reporting as a pest on peanuts especially in Indonesia. We described about pod borer attacking in West Sumatera and as alternative strategic control using entomopathogenic fungi bicontrol agents is safety and more efective and it will be promoted for controlling of larvae in pods under soil. The objective of this research were to determine severity of damage of pod borer with survey and observation methods, and to find out potential entomopathogenic fungi by in both of baiting and dilution method. The severity of attacking of pod borer on groundnut was 14 to 70\%. Five group of fungi i.e: Metharizium sp, Aspergillus sp, Trichoderma, Fusarium and Paecillomyces were isolated from soil of groundnut's rhizosphere in several districts of West Sumatera and they were able to infected of Tribolium molitor 8-30\%.
\end{abstract}

Keywords - entomopathogenic fungi, groundnut, rhizosphere, Etiella zinckenella

\section{INTRODUCTION}

Etiella zinckenella (Lepidoptera: Pyralidae) is an important pest. It is known as soybean pod borer. However, in a recent years, this pest has been detecting on peanut (Apriyanto et al., 2008). Actually it never reported in Indonesia (Kalshoven, 1987). The first reporting was from Province of Bengkulu which pod borers have damaged peanuts both at high and low land (Apriyanto et al., 2009). We have found the damage of pod borers on peanut since 2012 in West Sumatera especially in Pasaman Barat (Ganeshi, 2013). This pest due to loss yield significantly if there is no practicing of control at all. Its attacking undetected on peanuts because larvae bore inside pod under soil.

The use of chemicals is tested by farmers proved to be ineffective because the larvae live in pods that can not direct contact with chemicals. In contrast, the use of insecticides can be dangerous because it accumulates in the pod. Alternative controls are considered the most potential to be developed is the use of biological agents especially entomopathogenic fungi. This fungus can be applied directly to the soil around the root zone near the pod. Various types of entomopathogenic fungi can actually last long and multiply so that the potential for infecting larvae survive long in the soil because they are saprophyte.

The initial steps are necessary to take advantage of entomopathogenic fungi from rhizosphere for pod borer control peanut plants is knowing the diversity of fungi found in peanut cropping land. Several studies entomopathogenic fungi diversity in the rhizosphere of plants has been carried out. Samer research results (2011) indicate that there are four entomopathogenic fungi in the genus rhizosfir chilli crop in several locations in West Sumatra, namely Fusarium, Aspergillus, Trichoderma and Metarhizium. Hamdani (2009) further showed that the diversity of entomopathogenic fungi on cacao plantations rhizosphere strongly influenced by the agro-ecosystem conditions such as the type and altitude of cover crops and cultivation techniques. Under these conditions, an attempt to find entomopathogenic fungi that can play a role in the control of pod borer peanuts are easy and appropriate for farmers to be very important. This research aims to study and know the pod borer attack, and to study the diversity of entomopathogenic fungi around the roots which are peanuts that have the potential to control pod borer larvae in West Sumatra.

\section{MATERIALS AND METHODS}

\section{A. Survey of Peanut and Incidence of Pod Borer Attack}

Study of pod borer attack was conducted from April to August 2012. Survey was conducted by purposive sampling method in three subdistricts in Pasaman Barat, West Sumatra Province. In every district observed two planting area that 
almost harvested. Each of which was observed as many as 80 plant samples. All plant samples were collected then taken to the laboratory for counting pod damage, the symptoms of the attack, as well as observing the pod borer larvae.

\section{B. Collection and Isolation of Entomopathogenic Fungi}

Study of entomopatogenic fungi was conducted from November to December 2012 in the peanut-producing several districts in West Sumatra, the West Pasaman, Tanah Datar, Solok, Agam and the South Coast. Description of sites has shown in Table 1. The method used to collect soil entomopathogenic fungi of groundnut crop is stratified purposive sampling method. Collection is done on five district centers groundnut production in West Sumatra. In each district selected one location and at each of two locations were selected for sampling farmers' fields. Bean crop land selected is land previously planted peanuts.

Before entomopathogenic fungi isolated from soil planting peanuts, which are first ground around the roots of plants collected by excavated soil at a depth of $10-15 \mathrm{~cm}$ in the soil around the roots of bean plants using a small shovel. At each sampling site were taken 5 sample points specified diagonally. At 5 points are taken soil samples of 500 grams. Soil samples were then inserted into a plastic bag and labeled and stored in the cooler box. Soil samples were then taken to the laboratory for further processing. Isolation of fungi from soil was conducted using traps (bait method) using Tribolium molitor larvae and use the dilution method.

To isolate the fungus from the soil by trapping method (verse method), soil samples from each site cleared of plant roots, then crushed and sieved with a 600 mesh sieve. Land that has been treated earlier as much as 500 grams inserted into a plastic box measuring $15 \mathrm{~cm}$ x $10 \mathrm{~cm}$ x $10 \mathrm{~cm}$. Soil moistened with sterile water until the soil looks a little wet, then put 10-instar larvae of T. molitor 5 newly molted. The box is then incubated at room temperature (250C) for 10 days. Observation of $T$. molitor larvae infected performed every day. Dead larvae were removed and surface sterilized with $1 \%$ sodium hypoclorite and rinsed 3 times with sterile water. Further input into the petri dish was covered with moist filter paper and incubated for 12 days. Isolation of fungi from infected larvae done by taking conidia of fungi that grow on the outside of the body and the larvae were grown on medium SDAY and then purified.

Isolation of entomopathogenic fungi from soil was also carried out by the method of dilution by taking from each soil sample as much as 10 grams, then dissolved in $100 \mathrm{ml}$ of sterile akuadest who has given $0.05 \%$ tween 80 and in the vortex for 2 minutes. Soil suspension diluted (serial dilution) up to 3 times and $0.1 \mathrm{ml}$ of the suspension included in a petri dish containing medium has SDAY for isolation of entomopathogenic fungi. Petri dishes were incubated for 5 days and colonies of fungi isolated were there back then purified on SDAY media. Identification of fungi obtained macroscopic and microscopic done. Identification key is a key used Barnett and Hunter (1972), Poinar and Thomas (1984), and Watanabe (2002).
TABEL 1

Sites Of SAMPle Colection OF PeAnUts Rhizosphere SoIL IN WEST SuMATRA PROVINCE

\begin{tabular}{|c|c|c|}
\hline Sites & $\begin{array}{r}\text { Croping } \\
\text { system }\end{array}$ & $\begin{array}{l}\text { Species of } \\
\text { Plants }\end{array}$ \\
\hline $\begin{array}{l}\text { Nagari Lolo, district of } \\
\text { Pantai Cermin, District } \\
\text { Solok }\end{array}$ & polyculture & $\begin{array}{l}\text { peanut, banana, } \\
\text { corn, manihot }\end{array}$ \\
\hline $\begin{array}{l}\text { Nagari Muaro Kiawai, } \\
\text { subdistrict of Gunung Tuleh, } \\
\text { district of Pasaman Barat }\end{array}$ & polyculture & $\begin{array}{lr}\text { peanut, } & \text { sugarcane, } \\
\text { citrus, } & \text { corn, } \\
\text { banana } & \end{array}$ \\
\hline $\begin{array}{lll}\text { Nagari } & \text { Sungai } & \text { Buluh, sub } \\
\text { district } & \text { Matur, District of } \\
\text { Agam } & & \end{array}$ & $\begin{array}{l}\text { Monoculture, } \\
\text { and polyculture }\end{array}$ & Peanut, corn \\
\hline $\begin{array}{l}\text { Nagari Balimbiang, sub } \\
\text { district Rambatan, distric of } \\
\text { Tanah Datar }\end{array}$ & $\begin{array}{l}\text { monoculture, } \\
\text { and polyculture }\end{array}$ & Peanut, corn \\
\hline $\begin{array}{l}\text { Nagari Ganting Mudiak sub } \\
\text { ditrict of Sutera, district of } \\
\text { Pesisir Selatan }\end{array}$ & monoculture & peanut \\
\hline
\end{tabular}

\section{RESULT AND DISCUSSION}

\section{A. Description of Etiella zinckenella and Its Attacking on Peanut}

The larval form of E. zinckenella found is cylindrical shaped body and segmented, each segment there is a pair of legs, body length 3- $12 \mathrm{~mm}$ consisting of several instars, larval color green to red and black on the head. This body of larval instars can be seen in three to five instars.

In each pod attacked found hole size 1-1.5 mm. Holes generally at the base, middle and end of the pod. When pods peeled, seeds obtained were damaged partially or completely mixed with feces (Fig. 1). The larvae can devour whole seed, but usually only partially. Meanwhile, the remaining seed live saprophyte fungi that enter through the hole. Moreover, inside each pod always found feces larval support for the growth of saprophytic fungi. The presence of this fungi degrade the quality of seed so it can not be harvested at all.

Early instar usually entered by punching holes in the base ginofor (Apriyanto, 2010). Nearly all of the live larvae are inside the pod. Nevertheless, the possibility of the larvae can move from one pod to other pods. Late instar larvae more active so that it can move and destroy more than one pod in this phase. According to Djuwarso and Hartono (1998), E. zinckenella in each pod found only one larva because if more than one they will compete and cause one of them will move to the other pods. With such behavior tends to cause high levels of pod damage. Larvae were found to generally measure 8-10 mm with varying colors of green and reddish. Based on the size, the larvae belong to the 4th and 5th instar 


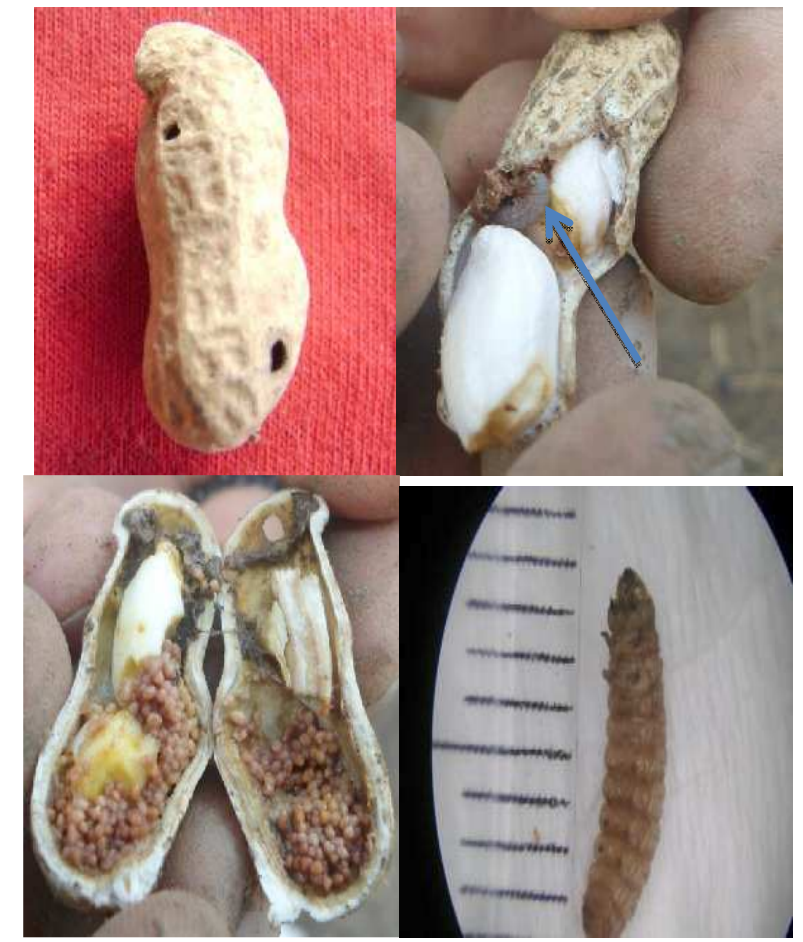

Fig 1. Holes on peanut pod and larvae feeding inside in pod (above), faeces remaing inside pod, and the $4^{\text {st }}$ instar larvae

\section{B. Incidence of Pod Borer Attack in West Pasaman}

Survey was conducted from April to August 2012 showed differences in the level of pod borer attacks on peanut plants in several locations (Table 2). All of clumps (100\%) was attacked in Sungai Aua and Koto Balingka. Pod attacked was higher At the these locations grown improved varieties (Domba), but at Gunung Tuleh that grown Domba and local variety not all attacked. Local varieties have tissue harder and more dense than Domba. Local varieties have a potential genetic resistance should be developed. Low rainfall during April to August 2012 to support the development of pod borer population. It was also reported that population higher in dry season than wet season on soybean in West Java and Midle Java (Soekarna and Tengkano, 1979).

TABLE II

The Percentage Of Clumps AtTACKed, Pods Attacked And DAMAGED SEEDS IN ThREE SUbDISTRICTS IN WEST PASAMAN

\begin{tabular}{|c|c|c|c|}
\hline $\begin{array}{c}\text { Sub } \\
\text { Districts }\end{array}$ & $\begin{array}{c}\text { Clumps } \\
\text { attacked } \\
(\boldsymbol{\%})\end{array}$ & $\begin{array}{c}\text { Pods attacked } \\
(\mathbf{\%})\end{array}$ & $\begin{array}{c}\text { Damage } \\
\text { seeds (\%) }\end{array}$ \\
\hline $\begin{array}{c}\text { Gunung } \\
\text { Tuleh }\end{array}$ & 70 & $14.4-26.1$ & 15.9 \\
\hline Sungai Aua & 100 & $61.1-64.4$ & 27.3 \\
\hline $\begin{array}{c}\text { Koto } \\
\text { Balingka }\end{array}$ & 100 & $67.6-72.6$ & 51.1 \\
\hline
\end{tabular}

\section{Fungi of Groundnut's Rhizosphere as Potentially Entomopathogenic}

Entomopathogenic fungi infection rates in $T$. molitor larvae depend on ground source or location (Fig.2). Of the four areas sampled, the percentage of $T$. molitor larvae infected with entomopathogenic fungi ranged between 8$30 \%$.

In addition to using the method of trapping insects with larvae of T. molitor, the isolation of entomopathogenic fungi from rhizosphere peanuts also performed with dilution method. Based on the results of the collection and identification of the isolates showed that the three regions found five sampling locations genus of entomopathogenic fungi that can be isolated from soil, namely Metarhizium (Deutoromycotina: Hyphomycetes), Trichoderma (Hypocreales: Hypocreaceae), Aspergillus (Eurotiales; Eurotiaceace), Fusarium (Hypocreales: Nectriaceace), and Paecilomyces (Eurotiales: Trichocomaceae). Based on the research results that have been obtained show that there are two types of the most dominant entomopathogenic fungi found in the peanut crop ecosystems Aspergillus and Metharhizium group . Both types of entomopathogenic fungi is found in all locations of planting peanuts. The genus Paecilomyces was found only in the location of the peanut crop in the propagation area. Some isolates were successfully collected can be seen in Table 3 .

TABLE III

Results Of A Collection Of ENTOMOPATHOGENiC Fungi From The RHIZOSPHERE OF PEANUT AT VARIOUS LOCATIONS

\begin{tabular}{|c|c|c|}
\hline \multirow{2}{*}{$\begin{array}{c}\text { Regions of } \\
\text { Origin }\end{array}$} & Genus & $\begin{array}{c}\text { Number } \\
\text { of isolates }\end{array}$ \\
\hline Matur (District of & Trichoderma & 2 \\
\cline { 2 - 3 } Agam) & Aspergillus & 2 \\
\cline { 2 - 3 } & Metarhizium & 4 \\
\cline { 2 - 3 } & Fusarium & 1 \\
\hline \multirow{2}{*}{$\begin{array}{c}\text { Rambatan } \\
\text { (District of Tanah } \\
\text { Datar) }\end{array}$} & Trichoderma & 2 \\
\cline { 2 - 3 } & Aspergillus & 8 \\
\cline { 2 - 3 } & Metarhizium & 14 \\
\cline { 2 - 3 } & Fusarium & 3 \\
\hline Gunung Tuleh & Paecilomyces & 2 \\
\cline { 2 - 3 } (District of & Metarhizium & 13 \\
\cline { 2 - 3 } Pasaman Barat) & Fusarium & 2 \\
\hline
\end{tabular}

The percentage of $T$. molitor larvae exhibiting symptoms of mycosis mostly in the peanut crop land from areas Surian (Solok district), which reached 30\%, and the lowest are found in the soil planting peanuts originating from the propagation (Tanah Datar) i.e $8 \%$. One of the causes of the high rate of infection in the entomopathogenic fungus $T$. molitor larvae of this is the high number of infective propagules in the soil. Tanada and Kaya (1993) suggested that the size of the inoculum density of the pathogen or is one of the important factors for the occurrence of infections in insects. In addition, factors may also affect the use of pesticides, to infection by entomopathogenic fungi. Intensive use of pesticides in areas negatively affect the propagation of entomopathogenic fungi against insect infections. The results of the study Sapieha-Waszkiewicz et al. (2005) found that the intensity of entomopathogenic fungi infection in Galleria mellonella larvae was higher in the soil planting grapes that are not applied with pesticides $(72.5 \%)$ compared with the planting soil with pesticides applied wines $(32.5 \%)$. In addition to pesticides, soil tillage intensity also affects the population of entomopathogenic fungi in soil. The results of 
the study Sosa-Gomez et al. (2001) showed that the population of entomopathogenic fungi in soil soybean higher in untreated soil compared to the cultivated land.

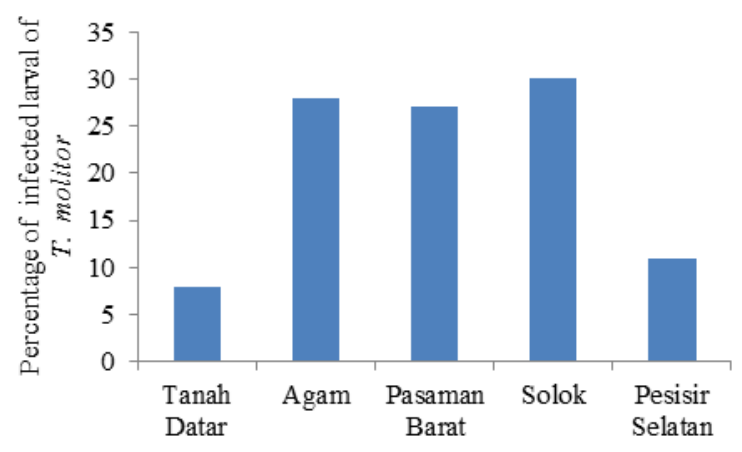

Fig.2. Mortality of T. molitor larvae infected with entomopathogenic fungi from several of soil collection sites

From the results obtained is also shown that in addition to entomopathogenic fungi Metarhizium and Aspergillus, other fungi found in soil throughout the sample site is Fusarium, while other entomopathogenic fungi such as Beauveria bassiana, Verticillium which can usually be found in the rhizosphere of plants, not found in the location sampling. Barker and Barker (1998) suggested that entomopathogenic fungi $B$. bassiana and $M$. anisopliae is more often found in grassland soil compared to forest land and agricultural land, while Paecilomyces cf cicadae only found in forest soils. This shows that Metarhizium, Aspergillus and Fusarium fungus is commonly found in soil and agricultural land where the fungus is also influenced by the location of the area. Samer research results (2011) get 4 types of rhizosphere chili entomopathogenic fungi, namely Fusarium, Aspergillus, Trichoderma and Metarhizium. In the area of flat ground and Solok found 3 types of fungi, while in Padang only 2 types of fungi were found. Fusarium and Aspergillus are found in all rhizosphere chili crop, whereas Trichoderma was found only in one location in Tanah Datar and Metarhizium in Solok. The results of the study LezamaGutierrez et al. (2001) showed that the ground maize and sorghum in the three Mexican states found that $M$. anisopliae, Beauveria bassiana and P. fumosoroseus. M. anisopliae was the most dominant species, found $25 \%$ of the entire sample locations, whereas $P$. fumosoroseus was only found in one location sampled (5\%). Bidochka et al. (1998) also reported that there are three types of entomopathogenic fungi found in soil samples from various locations in Notario (Canada) that M. anisopliae, B. bassina and Paecilomyces. $M$. anisopliae is more commonly found on agricultural land while $B$. bassina more commonly found in natural soil (natural). Molina-Ochoa et al. (2003) further found that from ground maize in Mexico found two types of entomopathogenic fungi $B$. bassiana and the M. anisopliae. Entomopathogenic fungus $M$. anisopliae is a type of fungus which is predominantly found in almost all locations.

The propagation from district of Tanah Datar has a species diversity and abundance of entomopathogenic fungi higher than in other areas, namely the five genera, while species diversity of entomopathogenic fungi found in the area of West Pasaman, the three genera. At least the type and number of fungi found in soil allegedly influenced by the physical and chemical properties of soil, altitude, soil temperature, crop types and cultivation techniques. In the area of the District. West Pasaman intensity of land management, the use of chemical fertilizers and pesticides are more intensive land for palm oil so it can also affect crop land planted peanuts, so it can affect the existence and distribution of entomopathogenic fungi in the soil. Existence, diversity and distribution of entomopathogenic fungi in soil is strongly influenced by soil organic matter content, $\mathrm{pH}$ and soil type, altitude, habitat, soil temperature, geographic location, environmental conditions, type of crop and cultivation practices (Ali-Shtayeh et al., 2003 ; Barker and Barker, 1998; Lezama-Gutierrez et al., 2001; Molina-Ochoa et al., 2003). The use of pesticides in the cultivation of peanuts can also suspected to influence the diversity of entomopathogenic fungi. Intensive pesticide application on groundnut crop can affect the survival of conidia in soil. According Sapieha-Waszkiewicz et al (2005) the presence of entomopathogenic fungi in soil is highly dependent on cultivation techniques and the use of pesticides Sudarmadji (1994) suggested that entomopathogenic fungi $B$. bassiana is very sensitive to the fungicide and insecticide BPMC mankozeb and somewhat sensitive to the insecticide endosulfan.

\section{CONCLUSIONS}

Damaged by pod borer in peanuts has a characteristic holes ranging in diameter from 1 to $1.5 \mathrm{~mm}$ located either at the base, midle and end of the pod irregularly. The larvae can devour whole seed, but usually only partially and found saprophyte fungi in the remaining seed. Incidence of pod borer attacking on groundnut was 14 to $70 \%$. Metharizium sp, Aspergillus sp, Trichoderma, Fusarium and Paecillomyces were groups of fungi as entomopathogenic succesfully isolated from soil of groundnut's rhizosphere and they were able to infected of Tribolium molitor 8-30\%.

\section{ACKNOWLEDGMENT}

We thank to the Higher Education of General Directorate funded by Competitive Fund Research 2013-2014

\section{REFERENCES}

[1] Ali-Shtayeh MS, Mara'I AB, RM Jamous. 2003 Distribution, occurrence and characterization of entomopathogenic fungi in agricultural soil in the Palestinian areas. Mycopathologia 156 (3): 235-244.

[2] Apriyanto, D. Sriwidodo and Pritiningsih. 2008 Incidence of Soybean Pod Borer on groundnut (Arachis hypogea L.) in Bengkulu. Journal Of Agrosia 1: 40 - 45.

[3] Apriyanto, D. Ogie Hendra Yoga and Andi Mulyadi. 2009 Appearances Soybean Pod Borer Etiella zinckenella Treischke (Lepidoptera: Pyralidae) and Host Selection of Soybean and Peanut. Journal of Agrosia 12 (1): 62-67.

[4] Apriyanto, D. Burhannudin Toha, Priyatiningsih and D. Suryati. In 2010. Resilience appearance Six Peanut Varieties Against Borers Pods (Etiella zinckenella Treitschke) in Plateau and mainland Low Bengkulu. Journal HPT Tropika.10 (1): 13-19.

[5] Bidochka MJ, Kasperski JE and Wild GAM. 1998 Occurrence of the entomopathogenic fungi Metarhizium anisopliae and Beauveria bassiana in soils from temperate and near-northern habitats. Can. J. Bot. 76: 1198-1204. 
[6] CW Barker, Barker GM. 1998 Generalist entomopathogens as biological indicators of deforestation and agricultural land use Impacts on Waikato soils. New Zealand Journal of Ecology 22 (2): 189-196.

[7] Ganeshi, J. 2013. Pod borer pest Etiella zinckenella (Lepidoptera: Pyralidae) in groundnut crop in West Pasaman. Thesis, University of Andalas

[8] Hamdani, 2009 Species Diversity entomopathogenic fungi that Being in In the Land of the Rhizosfir Cocoa in West Sumatra. [Thesis].

[9] Kalshoven, L.G.E. 1981. Pests of crops in Indonesia. PT. Ikhtiar Baru, Jakarta. 701 pp.

[10] Lezama-Gutierrez R, Hamm JJ, Molina-Ochoa J, Lopez-Edwards M, Pescador-Rubio A, Gonzalez-Ramirez M, Styer EL. 2001 Occurrence of entomopathogens of Spodoptera frugiperda (Lepidoptera: Noctuidae) in the Mexican States of Michoacan, Colima, Jalisco and Tamaulipas. Florida Entomologist 84 (1): 23-30.

[11] Marwoto. 2004 Prospect Trichogrammtoidea Parasitoids (Hymenotera) As Biological Agents For Controlling Pests Soybean pod borer Etiella zinckenella treit. By way of Inundation. [Dissertation] University Brawijaya Malang.

[12] Soekarna, D and W. Tengkano, 1979 Diversity and Succession Pests Soy. Congress of Entomology I. Jakarta. Association 1979 Indonesian Entomology. Jakarta.

[13] Molina-Ochoa J, Lezama-Gutierrez R, Gonzalez-Ramirez M, LopezEdwards M, Rodriguez-Vega MA, Palacios F. Arceo-parasitic nematodes and 2003 Pathogens associated with Populations of fall armyworm (Lepidoptera: Noctuidae) larvae in Mexico. Florida entomologist 86 (3): 244-253.

[14] Samer SHC. 2011. Diversity entomopathogenic fungi At Chili Crop Rhizosfir Highlands and Lowlands in West Sumatra. [Thesis]. Padang: Faculty of Agriculture. Andalas University.

[15] Sapieha-Waszkiewicz A, B Marjanska-CICHON, Piwowarczyk Z. 2005 The occurrence of entomopathogenic fungi in the soil from the plantations of black currant and Aronia. Electronic Journal of Polish Agricultural Universities 8 (1): 1-8.

[16] Tanada Y, Kaya HK. 1993 Insect Pathology. San Diego: Academic Press, INC. Harcourt Brace Jovanovich, Publishers. 